\title{
Properties of Agave angustifolia Haw. bagasse before and after its composting
}

\author{
Gabino A. Martínez-Gutiérrez, Yolanda D. Ortiz-Hernández*, \\ Teodulfo Aquino-Bolaños, Angélica Bautista-Cruz, Juana Y. López-Cruz \\ Instituto Politécnico Nacional, Mexico \\ *Corresponding Author, e-mail: yortiz@ipn.mx
}

\begin{abstract}
The industry of mezcal (Agave spp.) in Oaxaca, Mexico annually generates more than one hundred thousand tons of bagasse. With the aim of using this by-product as an alternative organic substrate, the physical, physicochemical and chemical properties of samples of A. angustifolia Haw bagasse were analyzed before and after composting. The analysis was carried out as a function of aging time, using 0,90 and 180 days of aging. Before composting, all the physicochemical properties were different for each of the aging periods except for humidity and dry matter. During the composting process the temperature of the three materials was superior to $50{ }^{\circ} \mathrm{C}$, and after 105 days mature compost, free of feces was obtained. The physicochemical and chemical properties of the three composts were different for each of the aging periods and most of them were not between the reference intervals, except in the $\mathrm{C} / \mathrm{N}$ relation. This is in contrast to most of the other physical properties.
\end{abstract}

Keywords: Biodegradation, organic fertilizer, organic substratum, reuse of residues

\section{Propriedades do bagaço de Agave angustifolia Haw. antes e após a sua compostagem}

\section{Resumo}

A indústria do agave (Agave spp.) em Oaxaca, México, gera anualmente mais de cem mil toneladas de bagaço. Com o alvo de utilizar este sub-produto como um substrato orgânico alternativo, foram analisadas as características físicas, físico-químicas e químicas de amostras de bagaço de A. angustifolia Haw antes e depois da compostagem. A análise foi realizada em função do tempo de maduração aos 0,90 e 180 dias. Antes de compostagem, todas as propriedades físico-químicas foram diferentes para cada um dos três tempos de maturação, exceto enquanto à umidade e a massa seca. Durante o processo da compostagem, a temperatura dos três materiais foi superior a $50^{\circ} \mathrm{C}$, e a compostagem foi conseguida após 105 dias, livre de fezes. As propriedades físico-químicas e químicas das três compostagens foram diferentes para cada um dos tempos de maturação sendo que a maioria não situou-se dentro das faixas de referência, exceto para relação $\mathrm{C} / \mathrm{N}$. Isto está em contraste com a maioria das propriedades físicas.

Palavras-chave: Biodegradação, adubo orgânico, substrato orgânico, reutilização de resíduos 


\section{Introduction}

The main productive zones of Agave spp. are located in the southern and western parts of Mexico. Processing of Agave spp. results in mezcal and tequila, two native alcoholic drinks with different odor and taste and that are exported due to their great economical importance.

The last decade, in the State of Oaxaca, the fields and processing of Agave spp. (maguey mezcalero) have increased significantly, in particular the one of A. angustifolia Haw (Figure 1A). This process has also generated important environmental problems due to the cultivation system and the by-products generated during the distillation process. Among the principal problems there is the elimination of waste waters called "vinazas", and the generation of bagasses, a sweet and fibrous residue derived from the extraction of the fermentable sugars from the core of the agave, called "piña" whose name is due to its similarity to the Ananas comosus fruit (Figure 1B and 1C). The industry of mezcal in Oaxaca annually produces 130 thousand tons of bagasse (COMERCAM, 2013). Every year this material is wasted in the rivers or it is minimally used as fuel, after being aged, in brick-kilns and agricultural soils. It causes great environmental damage because it is dumped without any biotransformation process.

Among possible transformation methods of organic materials with horticultural purposes, stand out aging and composting. In the first case, Abad et al. (2004) defines aging as the changes occurred in an organic material as a result of time, and mainly due to environmental factors under non-controlled conditions. The second case refers to the process mediated by fungi and bacteria (Klamer et al., 2001; Venegas et al., 2005), these organisms degrade hydrocarbonated molecules to form supramolecular humic materials (Piccolo, 2002). The composting process consists of a high degradation phase and a maturing phase; the first one is characterized by the action of microorganisms over the less complex substances, and the second one by the transformation of recalcitrant components in humic substances which improves the substrate quality (Genevini et al., 2002). Abad et al. (2004) stated that when there is a $\mathrm{C} / \mathrm{N}$ value inferior to 40, the organic material is mature and stable, and it is also suitable to be used for the cultivation of vegetables; on the other hand, Iglesias and Pérez (1992) point out that the right value should be a $\mathrm{C} / \mathrm{N}$ of 12.

In several studies, it has been demonstrated that the $A$. tequilana Weber bagasse when mixed with grains and cereals, represents a feeding source for animals (Íñiguez et al., 2001), and that composting it could generate a substrate for tomatoes cultivation (Íñiguez et al., 2011).

The objective of this work was to determine some physical, physicochemical, chemical properties of agave bagasse with 0, 90 and 180 days of aging that was subjected or not to composting.

\section{Material and Methods}

The raw material of A. angustifolia Haw. was obtained from the traditional distilleries "Platas de Reyes" in San Juan Guelavia, Oaxaca, Mexico (16 57' 19' 'LN and $97^{\circ} 27^{\prime}$ ' 15' ' LE). The baking of the "piñas" (Figure 1D and 2A) was done using a soil oven and it was grinded with a circular stone moved by animal traction (Figure 2B). After this process, the grinded "piñas" were put into wooden tubs for its fermentation (Figure 2C). The obtained product was a triturated paste of fiber with pith (called agave bagasse (Figure 2D) and alcohol. Then the alcohol was extracted by distillation made in a clay pot with a copper serpentine, the separated bagasse still contained a low percentage of alcohol.

Three treatments were tested for bagasse with 0,90 and 180 days of aging (Figures 2D and $2 \mathrm{E}$ ) using three piles of bagasse for each treatment. Each pile had a volumen of $8 \mathrm{~m}^{3}$. Both the composted and aged piles were evaluated under a random trial in triplicate. Each pile of material was considered a trial.

The materials with 90 and 180 days of aging stayed unmoved, and after these times they were kept in paper bags of 25 liters and were put in a dry and fresh place. For the chemical characteristics of the non-composted bagasse of the three materials of A. angustifolia; there were taken, from the central part of each pile, 12 liters per material. 


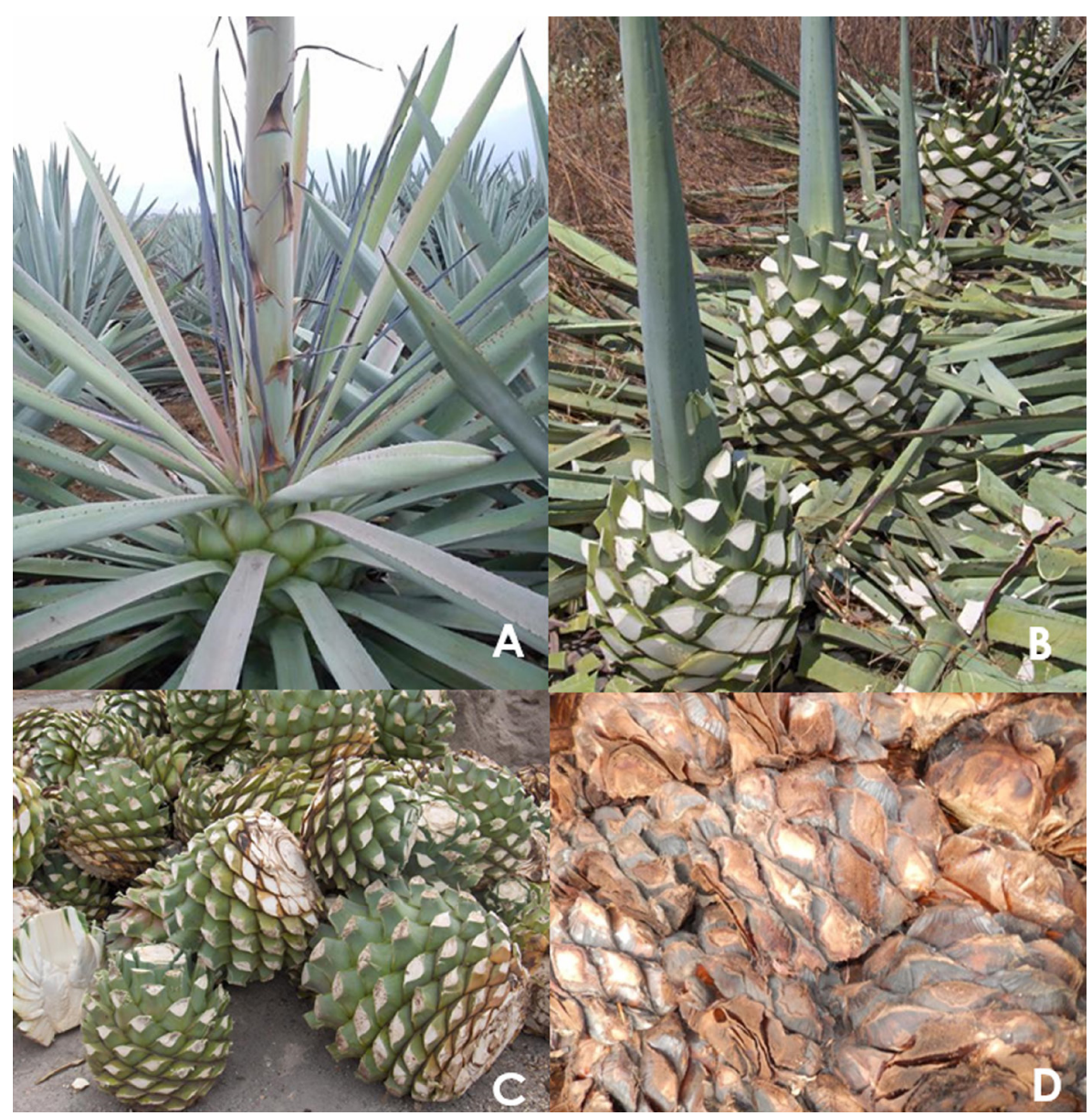

Figure 1. A) Mature Agave angustifolia Haw. suitable for processing. B) Removing the leaves to obtain "piña". C) "piñas" before baking. D) "piñas" baked.

The three materials with 0,90 and 180 days of aging were exposed to a composting process which consisted in moving and moistening every 105 days the material as it was proposed by íñiguez et al. (2011). The internal temperature of the piles was monitored every seven days using nine dial thermometers of 13 centimeters of diameter with a stick of 60 centimeters of length (three per pile).

After the composting (Figure 2F), samples of the three matured composts were obtained by separating the piles longitudinally in two parts, taking from one of them, two liters of nine randomly selected points (in the inferior, medium and superior part of the pile), to obtain 18 liters of sample which were homogeneously mixed. Two subsamples of nine liters each one, were subjected to physicochemical and chemical analysis, and the physical characterization was done with the other one. All the physical, physicochemical and chemical determinations were done in triplicate.
Determination of Physicochemical and chemical properties. The $\mathrm{pH}$ was measured with a Hanna potentiometer model PH 211. The $\mathrm{pH}$ is a parameter which indicates the degree of humification of the organic matter, at the beginning it is less than 5.5 owing to the generation of organic acids with low molecular weight, but when the compost reach maturity, the $\mathrm{pH}$ increases to alkaline values superior to 7.5 (Lee et al., 2002). The electrical conductivity (EC) and temperature were registered with an Extech conductivity/temperature meter model 407303, both following the saturation method extracts (Warncke, 1986). The total organic carbon (TOC) was calculated with the equation: $\%$ TOC $=(100$ - ashes)/1.8 (Golveke, 1977).

The number of anions $\left(\mathrm{Cl}^{-}, \mathrm{NO}_{3}^{-}\right.$, and $\left.\mathrm{H}_{2} \mathrm{PO}_{4-}\right)$, cations $\left(\mathrm{Ca}^{2+}, \mathrm{Mg}^{2+}, \mathrm{K}^{+}\right.$and $\left.\mathrm{Na}^{+}\right)$, and microelements ( $\mathrm{Zn}, \mathrm{Cu}, \mathrm{Fe}, \mathrm{Mn}$ and $\mathrm{B}$ ) were obtained by saturation paste extract (Warncke, 1986), using a chromatograph AS4A, with a CS12 cation column according to the method 
described by Gil de Carrasco et al. (1994), both expressed in $\mathrm{mmol}_{\mathrm{c}} \mathrm{L}^{-1}$. Total Nitrogen (TN) was taken per macro Kjeldahl (AOAC, 1984). The humidity or dry matter was obtained out of a sample exposed during 24 hours to $\pm 105^{\circ} \mathrm{C}$ and the content of ashes in a muffle furnace to $\pm 550^{\circ} \mathrm{C}$ during 2 hours (AOAC, 1984). The $\mathrm{C} / \mathrm{N}$ relation was calculated considering the previous carbon and nitrogen analysis. The cellulose and hemicellulose determinations were done with the neutral detergent fiber (NDF), acid detergent fiber (ADF), and acid lignin detergent (ALD), according to the technique described by Georing and Van Soest (1970). The content of hemicellulose was calculated by the difference of the (ADF) and (NDF). The loss of organic matter (OM), TOC and nitrogen were calculated according to the equations established by Îñiguez et al. (2006), and field density was determined by the TMECC (2001) technique.

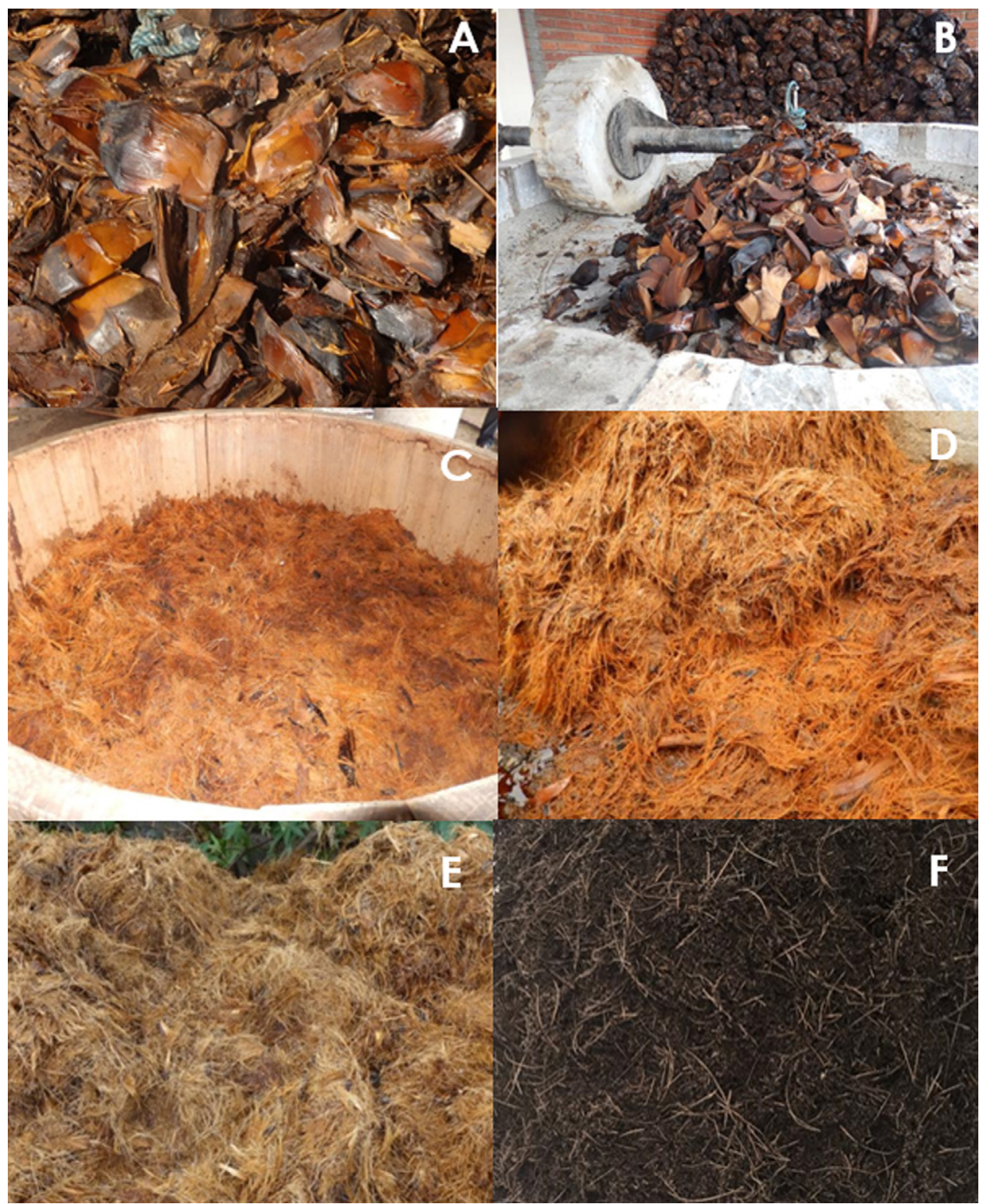

Figure 2. A) "piña" broken after baking. B) The piñas are grinded with stone wheel pulled by a horse or mule. C) Fermentation of agave for produce mezcal. D) Agave waste after fermentation and distillation yields, bagasse with 0 days of aging. E) Bagasse of 90 or 180 days of aging. F) compost bagasse. 
Determination of Physical properties. The distribution of particle size was analyzed (expressed as a percentage in weight), and the contraction of volume after the drying to $105^{\circ}$ (Richards et al., 1986; Martínez, 1992). The real density (RD), apparent density (AD), total porous space (TPS), and the capacity of water retention (WRC) were done by the method proposed by De Boodt and Verdonck (1972), and the air-water relation was done by the method proposed by De Boodt et al. (1974).

An analysis of variance (ANOVA) to determine the relation between the uncomposted and composted bagasse with different aging periods, considering the physical, physicochemical and chemical properties. When the ANOVA was significant, the Tukey test ( $P \leq 0.05)$ was applied. The statistical analysis was done using the SAS program version 9.0 (SAS Institute, 2002).

\section{Results and Discussion}

Temperature monitoring during the composting process.

In general, the three materials behaved according to the expected tendency for internal temperature in organic materials (Ross et al., 2006). During the first five days of composting (mesophilic stage), owing to the present microorganisms in the piles, and by effect of the fast hydrolysis of the available organic matter (Íñiguez et al., 2011), the internal temperature of the three materials linearly increased (Figure $\left.3, R^{2}=0.92, P \leq 0.01\right)$. The sharp decreases in temperature were due to the stirring of the materials done to facilitate its airing and water addition. After 14 days of composting, the maximum internal temperatures of the bagasse with 0,90 and 180 days of aging were of $50^{\circ} \mathrm{C}$, $64^{\circ} \mathrm{C}$, and $60^{\circ} \mathrm{C}$ respectively, and the composting of materials was finished after 105 days.

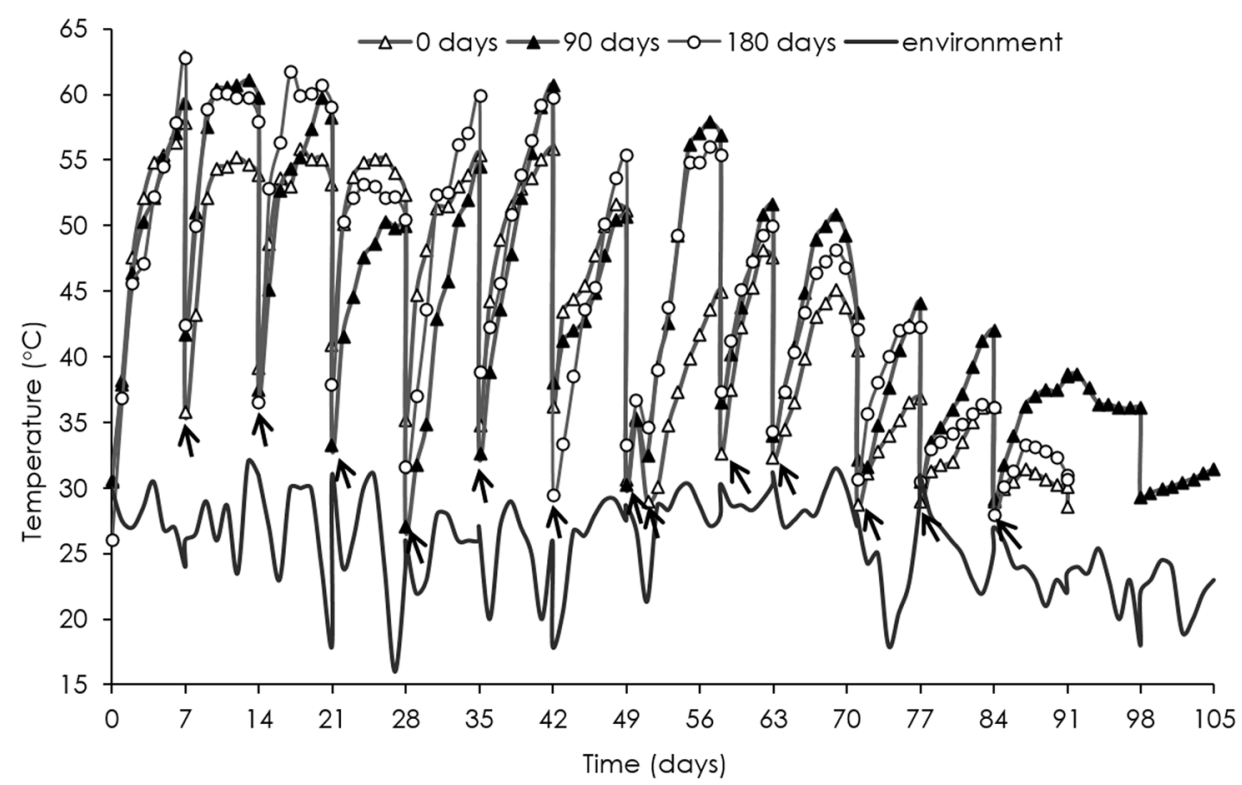

Figure 3. Behavior of the temperature in the inner part of the piles of A. angustifolia bagasse with different aging periods, compared to environmental temperature. Arrows indicate the days when the materials were stirred.

During the first 50 days, the internal temperature of the three materials was superior to $50^{\circ} \mathrm{C}$. Similar results were found in the composting of material of the tannery industry (Íñiguez et al., 2003), which reached temperatures of $54^{\circ} \mathrm{C}$ in the first 14 days. Also, in the composting of vineyard wastes with mud from a residual waters treatment plant there were obtained temperatures of $74^{\circ} \mathrm{C}$ after 54 days (Bertran et al., 2004). In the composting of biosolids with $A$. tequilana bagasse, there were registered temperatures of $65^{\circ} \mathrm{C}$ in the first 18 days (Íñiguez et al., 2006), and in the composting of $A$. tequilana bagasse added with ammonium nitrate there were obtained temperatures of $60^{\circ} \mathrm{C}$ after 50 days of composting (Íñiguez et al., 2011). 
The values of the internal temperature of the piles were located within the recommended by Rynk (1992) and The World Health Organization (WHO, 2006), which suggest that the organic materials should have and keep a temperature superior to $50^{\circ} \mathrm{C}$ during one week to get rid of any feces (EFSA, 2007).

The environmental temperature was never superior to the internal temperature of the composting. At the end of the composting process the three materials presented a dark color and a similar odor to gardening soil; nevertheless coarse particles remained.

Physicochemical and chemical properties of the composts.

Some of the physicochemical properties of three materials of "mezcalero agave" bagasse (A. angustifolia Haw) and their derived composts are shown in Table 1. Before the composting, it is observed that, except for cellulose and acid lignin detergent (ALD), the other physicochemical properties were highly different $(\mathrm{P} \leq 0.01)$.
The new or fresh material, had more humidity in relation to the one with 180 days; on the contrary, the percentage of dry matter linearly increased with the aging period $\left(R^{2}=0.93\right.$, $\mathrm{P} \leq 0.01$ ), the same with the $\mathrm{pH}$, which was of 5.32 in the new material, and as the time passed it was of 7.96 , being this value superior to the one reported by íñiguez et al. (2006 and 2011) for fresh $A$. tequilana bagasse and in organic materials of garden trees (Cabañas-Vargas, 2005), which is attributed to the consumption of the short-chain organic acids by thermophile bacteria in the interior of the piles of the material in decomposition process (Nakasaki et al., 1993; Sundberg et al., 2004).

The electrical conductivity (E.C.) of the new material of $\mathrm{A}$. angustifolia was of $1.37 \mathrm{dSm}^{-1}$, very close to the $1.31 \mathrm{dSm}^{-1}$ value found in A. tequilana bagasse (Íñiguez et al., 2011), however the E.C. of the materials with 90 and 180 days of aging were higher.

Table 1. Physicochemical properties of three materials of A. angustifolia bagasse and its composts.

\begin{tabular}{|c|c|c|c|c|c|c|c|c|c|}
\hline \multirow{3}{*}{ Property } & \multicolumn{3}{|c|}{ Before the composting } & \multicolumn{4}{|c|}{ After the composting } & & \multirow[b]{3}{*}{ R.I. } \\
\hline & \multicolumn{8}{|c|}{ Aging periods (days) } & \\
\hline & 0 & 90 & 180 & & 0 & 90 & 180 & & \\
\hline Humidity (\%) & $80.60 a^{1}$ & $68.87 b$ & $43.16 \mathrm{C}$ & * & $66.38 a$ & $58.85 a$ & $59.95 a$ & n.s & $45.7^{a}$ \\
\hline Dry matter (\%) & $9.40 c$ & $31.13 b$ & $56.84 a$ & * & $33.62 a$ & $41.15 a$ & $40.04 a$ & n.s & $54.3^{a}$ \\
\hline $\mathrm{pH}$ & $5.32 \mathrm{C}$ & $7.52 b$ & $7.96 a$ & * & $7.37 c$ & $7.70 a$ & $7.61 \mathrm{~b}$ & $*$ & $5.5-6.3^{+}$ \\
\hline E.C. $\left(\mathrm{dS} \mathrm{m}^{-1}\right)$ & $1.37 \mathrm{c}$ & $1.90 \mathrm{~b}$ & $2.24 a$ & $*$ & $1.77 b$ & $1.79 a$ & $1.64 \mathrm{C}$ & * & $2.0-3.5^{\dagger}$ \\
\hline Field Density $\left(\mathrm{kg} \mathrm{m}^{-3}\right)$ & $106.50 a$ & $80.80 \mathrm{~b}$ & $79.40 \mathrm{~b}$ & $*$ & $166.90 c$ & $242.30 \mathrm{~b}$ & $278.50 a$ & * & $142.0^{a}$ \\
\hline Ashes (\% DB) & $10.24 a b$ & $7.05 b$ & $14.11 a$ & * & $30.22 c$ & $38.01 \mathrm{~b}$ & $40.69 a$ & * & $18.6^{a}$ \\
\hline Organic matter (\% DB) & $89.76 a b$ & $92.95 a$ & $85.89 b$ & $*$ & $69.77 a$ & $61.99 b$ & $59.31 c$ & $*$ & $>80^{\dagger}$ \\
\hline (COT, \% DB) & $49.87 \mathrm{ab}$ & $51.64 a$ & $42.72 b$ & $*$ & $38.76 a$ & $34.44 b$ & $32.95 c$ & * & $42.5^{a}$ \\
\hline (TKN, \% DB) & $0.38 c$ & $0.56 a$ & $0.44 b$ & * & $1.81 \mathrm{a}$ & $1.21 \mathrm{c}$ & $1.52 \mathrm{~b}$ & * & $3.1^{a}$ \\
\hline C/N Relation & $131.24 a$ & $97.09 c$ & $92.17 b$ & $*$ & $21.39 b$ & $27.27 a$ & $21.69 b$ & * & $20-40^{\dagger \dagger}$ \\
\hline Hemicellulose (\%, DB) & $28.32 a$ & $8.83 b$ & $6.47 c$ & $*$ & $9.92 a$ & $5.90 \mathrm{~b}$ & $6.75 b$ & * & $3.4^{a}$ \\
\hline Cellulose (\%, DB) & $41.09 a$ & $44.85 a$ & $47.30 a$ & n.s. & $41.10 a$ & $38.97 a$ & $30.22 b$ & * & $14.4^{a}$ \\
\hline$(\operatorname{LAD}(\%, \mathrm{DB})$ & $10.68 a$ & $13.06 a$ & $10.85 a$ & n.s & $9.01 a$ & $6.40 \mathrm{~b}$ & $10.14 a$ & * & $264.00^{t+t}$ \\
\hline
\end{tabular}

Means followed by the same letter within bagasse aging periods, with or without composting, do not differ significantly by Tukey test at $P<0.05 .{ }^{*}$ Significance to the levels of probability of 0.05; n.s. no significant; (t)Abad et al. (1993), (t+1)Abad et al. (2000), "ttAbad et al. (2002) values for Sphagnum peat (g kg-1 dry weigh); a: Iñiguez et al. (2011); DB: Dry basis; R.I. Reference interval.

The field density decreased with the aging period, the highest value of $106.5 \mathrm{~kg} \mathrm{~m}^{-3}$ was presented in the new material and it was lower to the $123.9 \mathrm{~kg} \mathrm{~m}^{-3}$ reported by íniguez et al. (2011) in new fresh A. tequilana bagasse.

The increasing of the dry matter, $\mathrm{pH}$, E.C., and decreasing of field density in the aged materials, can be associated to the content of pith in the A. angustifolia bagasse which depends of the artisanal or industrial methods for the fermentable sugar extraction of the "piñas", as reported by Íñiguez et al. (2011) with A. tequilana bagasse.

The content of ashes, organic matter, total organic carbon (TOC), total Kjeldahl nitrogen (TKN) and acid fiber detergent (AFD) did not show a defined tendency and their values were similar to the ones found in fresh $A$. tequilana bagasse (íñiguez et al., 2011).

The Carbon/Nitrogen relation (C/N) 
decreased with the aging period, from 131.24 at 0 days of aging to 92.17 after 180 days of aging. The reduction of the $\mathrm{C} / \mathrm{N}$ relation, in the three aging-periods materials, was not enough to reach its stability and maturity, that is why it was necessary to do a composting process as it was indicated by Burés (1997) and Bernal et al. (1998) for organic materials and thus reach the value for growing substratum of $20-30$ as indicated by Abad et al. (2000).

The value of the neutral detergent fiber (NDF) (non-showed data) and the hemicellulose, decreased with the aging period. The content of cellulose of the three materials of $\mathrm{A}$. angustifolia bagasse was higher than the $A$. tequilana bagasse in fresh conditions as it was pointed by Íniguez et al. (2011). The content of acid lignin detergent (ALD), in the three analyzed materials was lower than the one reported by Abad et al. (2002) in coconut fiber and Sphagnum peat.

After composting, all the values of the physicochemical properties of the three materials were significantly different $(P \leq 0.01)$, except for the humidity and dry matter (Table 1). The $\mathrm{pH}$ values were slightly higher to the reference for gardening substratum, indicated by Abad et al. (1993), opposing to electrical conductivity (E.C.) values which were lower as it was also indicated by Abad et al. (1993). These values can affect the growing of certain sensitive plants (Bunt, 1988); however it has been demonstrated that the $\mathrm{pH}$ and E.C substrate values of 7.7 and 1.7 respectively, do not perform any risk for its use, because the watering and fertigation programs applied during the development of the growing tomatoes and flowers in containers (Abad et al., 2002), provokes an effective leaching of excessive soluble salts (Noguera et al., 1997 and 2000).

The field density and ashes percentage of the three composted materials linearly increased $\left(R^{2}=0.98 ; R^{2}=0.87, P \leq 0.01 ;\right.$ respectively $)$ overcoming the reference value indicated by Íñiguez et al. (2011) for A. tequilana bagasse that were $142.0 \mathrm{~kg} \mathrm{~m}^{-3}$ and 18.6, in the same order, owing to the content of pith and fiber of each material, which was strongly related to the grinding process of the "piña" and the traditional distillation method, including the bagasse storage outside the "palenque".

The organic matter (OM) of the composted material coming from the non-aging material, was higher than the other two materials, without overcoming the reference interval (> $80 \%$ DM) and it showed a slight reduction with the aging period. A similar result was found was found by Ansorena (1994) for pine bark and wood flakes as new organic materials reused in a crop cycle. Also this author mentions that in the induced or natural composts, the organic materials experiment a serie of changes in its chemical composition, until they reach a certain biological stability, opposite to what Puustjärvi (1994) mentions for the Sphagnum peat, which when it is submitted during long periods of time to natural biologic degradation processes it does not show a decomposition process in short time and it has high stability.

In the three materials, the total content of organic carbon of $A$. angustifolia was lower than the one of the A. tequilana (42.5\%) pointed by íniguez et al. (2011). The content of total nitrogen (TKN) was also low without overcoming the value of $1.81 \%$, and it was close to the almond shell with 165 days of use as substratum in vegetable crops (2.34\%) (Martínez-Gutiérrez and Urrestarazu, 2012), therefore the carbon nitrogen $(\mathrm{C} / \mathrm{N})$ relation as an indicator of the compost organic matter, its maturity and stability, showed differences $(P \leq 0.01)$ among the aging periods.

With the composting process, the $\mathrm{C} / \mathrm{N}$ relation of the three materials decreased and it was placed between the reference intervals for crops substratum (20-40) (Abad et al., 2000). This indicates that, unlike to the new material $(0$ days) or few decomposed (90 and 180 days), with composting, the organic matter of the three materials reached their maturity and chemical stability through humification (Burés, 1997; Bernal et al., 1998). This decreasing in the values of $C / N$ relation through composting, was also found in municipal waste compost (Herrera et al., 2008), vegetables waste compost of greenhouse horticulture (Urrestarazu et al., 2008) and in almond shell as a reused substratum in tomato and melon alternated crops (Martínez-Gutiérrez et al., 2009).

On the other hand, the composting 
process decreased the content of hemicellulose mainly in the new material (9.92\%), but the three materials showed higher values than the ones obtained in A. tequilana by Íñiguez et al. (2011), something similar occurred with the content of cellulose. These authors indicate that bagasses like the one of $A$. tequilana, are considered lignocellulosic residues, that is why they have scant nitrogen content, which can be overcome throughout the use of conventional fertilization programs if these materials are used as a growing medium (Abad et al., 2002).

The content of acid lignin detergent (ALD) was very low in the three composted materials compared to $A$. tequilana compost (Íñiguez et al., 2011), therefore they will perform a considerable resistance to the microbial degradation as it was pointed by Abad et al. (2002) in coconut coir dust.

Regarding the chemical characteristics of the three composts, the content of macroelements $\left(\mathrm{mmol}_{\mathrm{c}} \mathrm{L}^{-1}\right)$ in the extraction of the saturated paste, was significantly different ( $p$ $\leq 0.05$ ) for assimilable cations and anions, except for the $\mathrm{Ca}^{2+}$ and $\mathrm{H}_{2} \mathrm{PO}_{4}$ ions (Table 2), despite this, the cations and anions were placed between the reference intervals for substra $\square$ tes according to Abad et al., (1993 and 2000).

Table 2. Anions, cations and microelements content in saturation extract, of three A. angustifolia bagasse composts with different aging periods.

\begin{tabular}{|c|c|c|c|c|c|}
\hline \multirow{3}{*}{ Element } & \multicolumn{3}{|c|}{ Days of aging } & \multirow{3}{*}{ Significance } & \multirow{3}{*}{ Reference intervals } \\
\hline & 0 & 90 & 180 & & \\
\hline & \multicolumn{3}{|l|}{$\left(\mathrm{mmol}_{c} \mathrm{~L}^{-1}\right)$} & & \\
\hline $\mathrm{Ca}^{2+}$ & $6.4 a^{1}$ & $6.0 \mathrm{a}$ & $6.2 a$ & n.s. & $>5.0^{2}$ \\
\hline $\mathrm{Mg}^{2+}$ & $3.7 \mathrm{a}$ & $3.4 \mathrm{~b}$ & $3.5 \mathrm{~b}$ & $*$ & $>2.91^{2}$ \\
\hline $\mathrm{Na}^{+}$ & $4.3 \mathrm{~b}$ & $5.5 a$ & $4.5 b$ & * & $1-10-11.36^{3}$ \\
\hline $\mathrm{K}^{+}$ & $3.9 \mathrm{~b}$ & $5.2 \mathrm{a}$ & $4.0 \mathrm{~b}$ & * & $3.84-6.38^{2}$ \\
\hline $\mathrm{CL}^{-}$ & $4.0 \mathrm{~b}$ & $5.2 a$ & $4.8 \mathrm{~b}$ & * & $0.79-44.29^{3}$ \\
\hline $\mathrm{NO}^{3-}$ & $5.7 \mathrm{a}$ & $5.5 \mathrm{~b}$ & $5.6 a$ & * & $5.55-11.05^{2}$ \\
\hline $\mathrm{H}_{2} \mathrm{PO}_{4}^{-}$ & $0.2 \mathrm{a}$ & $0.2 \mathrm{a}$ & $0.3 a$ & n.s. & $0.06-0.10^{2}$ \\
\hline $\mathrm{Zn}$ & $21.6 a$ & $21.3 a$ & $23.3 a$ & n.s. & $0.3-3.0^{3}$ \\
\hline $\mathrm{Cu}$ & $1.7 \mathrm{~b}$ & $2.7 \mathrm{a}$ & $1.7 \mathrm{~b}$ & $*$ & $0.001-0.5^{3}$ \\
\hline $\mathrm{Fe}$ & $4.5 \mathrm{~b}$ & $5.4 a$ & $4.5 \mathrm{~b}$ & * & $0.3-3.0^{3}$ \\
\hline$M n$ & $2.4 \mathrm{C}$ & $6.9 a$ & $4.7 \mathrm{~b}$ & $*$ & $0.02-3.0^{3}$ \\
\hline B & $9.9 \mathrm{a}$ & $9.3 \mathrm{a}$ & $9.5 \mathrm{a}$ & n.s. & $0.05-0.5^{3}$ \\
\hline
\end{tabular}

The content of microelements of the three compost of A. angustifolia bagassef, also showed significant differences ( $p \leq 0.05$ ), except $\mathrm{Zn}$ and $\mathrm{B}$, which together with the content of $\mathrm{Fe}$, $\mathrm{Mn}$ and $\mathrm{Cu}$, were higher than the recommended by Abad et al., (2000) and the data reported by Vargas et al., (2008) in substrates of coconut coir dust. These high values principally in the content of microelements: $\mathrm{Zn}, \mathrm{B}, \mathrm{Fe}$ and $\mathrm{Mn}$; which may be associated with soil application of organic fertilizers and ashes, the latter derived from the burning of crop residues before and during the cultivation of $\mathrm{A}$. angustifolia as mentioned by Bautista et al. (2011), because no fertilizer was applied.

\section{Physical properties of the composts}

The bagasse compost with 180 days of aging, had the best granulometric balance, containing $3.81 \%$ of fine particles, $75.69 \%$ of medium particles and $20.50 \%$ of coarse ones (Table 3). This granulometric balance can improve some physical properties as air-water relation, as it was showed in perlite substratum by Marfá et al. (1993) and almond shell reused as a substratum in the alternated crops of melon and tomatoes (Martinez-Gutiérrez et al., 2009).

With the composting process, the real density (RD) and apparent density (AD) slightly increased in the three materials (Table 4). The RD values found were placed between the reference interval (1.45-2.65 $\mathrm{g} \mathrm{cm}^{-3}$ ) reported by Abad et al. (2000) for growing mediums. Regarding the total porous space (TPS) the values found for the materials with 0 and 90 days resulted suitable for growing mediums (>85\%) (Abad et al., 2000). As 
for the bagasse with 180 days of aging the value of total porous space (TPS), resulted slightly lower (83.37\%) compared to reference (>85\%) (Abad et al., 2000), owing to the higher percentage in weight of fine particles and lower in coarse particles.

The aeration capacity (AC) increased with the aging periods, without overtaking the interval reference. This behavior can be associated with the best granulometric distribution presented in the compost with 180 days of aging which have the higher stacking time and the higher percentage weigh of fine particles $(3.81 \%)$ than the materials with $0(0.35 \%)$ and 90 days $(0.03 \%)$. Similar results were found by Martínez-Gutiérrez et al. (2009) in the almond shell substratum reused up to 695 days.
The values of the air-water relation of the three composts varied regarding the aging (Table 4). The easily available water linearly increased and, after 90 days, it was placed between the reference intervals indicated by Abad et al. (1993), while the reserve water decreased after 180 days and it was lower than the reference (Abad et al., 2000). As a result of the addition of the two last properties, the total available water did not have great variations and the values of the three materials were placed between the reference intervals (Abad et al., 2000), while the hardly available water, increased with the aging. The behavior of this last property is similar to the one found by Martínez-Gutiérrez et al. (2009) in almond shell.

Table 3. Granulometric distribution of three composts of A. angustifolia bagasse as a function of aging.

\begin{tabular}{lccc}
\hline Particle size $(\mathrm{mm})$ & \multicolumn{3}{c}{ Days of aging } \\
\cline { 2 - 4 } & & $\begin{array}{c}90 \\
\text { (\% in weight) }\end{array}$ & 180 \\
\hline Fine & 0.11 & 0.03 & 0.83 \\
$<0.125$ & 0.24 & 0.08 & 2.98 \\
0.125- 0.25 & 0.35 & 0.11 & 3.81 \\
Total & & & \\
Medium & 5.55 & 0.56 & 7.47 \\
$0.25-0.42$ & 40.94 & 24.55 & 36.48 \\
$0.42-1.18$ & 13.10 & 20.31 & 13.39 \\
$1.18-2.0$ & 17.00 & 19.49 & 18.35 \\
$2.0-4.75$ & 76.59 & 64.91 & 75.69 \\
Total & & & \\
Coarse & 6.32 & 12.46 & 8.65 \\
$4.75-9.5$ & 6.29 & 11.67 & 6.55 \\
$9.5-16$ & 10.45 & 10.85 & 5.30 \\
$>16$ & 23.06 & 34.98 & 20.50 \\
Total & & & \\
\hline
\end{tabular}

Table 4. Physical properties of three materials of A. angustifolia bagasse at the end of its composting.

\begin{tabular}{|c|c|c|c|c|c|}
\hline \multirow[b]{2}{*}{ PROPERTY } & \multicolumn{3}{|c|}{ Days of aging } & \multirow[b]{2}{*}{ Significance } & \multirow[b]{2}{*}{ Reference intervals } \\
\hline & 0 & 90 & 180 & & \\
\hline Real density $\left(\mathrm{g} \mathrm{cm}^{-3}\right)$ & $1.72 c^{1}$ & $1.79 \mathrm{~b}$ & $1.82 \mathrm{a}$ & $*$ & $1.45-2.65^{(\dagger)}$ \\
\hline Aparent density $\left(\mathrm{g} \mathrm{cm}^{-3}\right)$ & $0.19 \mathrm{C}$ & $0.26 \mathrm{~b}$ & $0.30 a$ & * & $<0.4^{(\dagger)}$ \\
\hline Total porous space (\%) & $88.53 a$ & $88.12 b$ & $83.37 \mathrm{c}$ & * & $>85^{(\dagger)}$ \\
\hline Aeration capacity $(\% \mathrm{v} / \mathrm{v})$ & $11.47 \mathrm{C}$ & $14.88 \mathrm{~b}$ & $16.63 a$ & $*$ & $10-30^{(t)}$ \\
\hline Air- water relation & & & & & \\
\hline Easily available water (\% v/v) & $14.27 \mathrm{~b}$ & $18.69 \mathrm{~b}$ & $34.66 \mathrm{a}$ & $*$ & $20-30^{(t)}$ \\
\hline Reserve water (\% v/v) & $10.76 a$ & $04.76 \mathrm{~b}$ & $02.17 \mathrm{~b}$ & * & $04-10^{(t)}$ \\
\hline Total available water(\% v/v) & $25.03 b$ & $23.45 \mathrm{~b}$ & $36.83 a$ & * & $24-40^{(t+)}$ \\
\hline Hardly available water(\% v/v) & $04.67 c$ & $21.56 \mathrm{~b}$ & $27.88 a$ & $*$ & n.d. \\
\hline
\end{tabular}




\section{Conclusions}

The A. angustifolia bagasse, new or aged, required a composting process. The three materials reached temperatures higher than $50^{\circ} \mathrm{C}$, independently of the aging periods to obtain mature composts free of feces. After 105 days of composting, the physical properties, the physicochemical and chemical properties of the three composts were different for each one for the aging periods and most of them were not between the reference intervals, except for the $\mathrm{C} / \mathrm{N}$ relation.

\section{Acknowledgements}

The authors thank Instituto Politécnico Nacional for financial support through the project SIP-20120828, and especially thank PhD. Gilberto Íñiguez Covarrubias of the Wood, Cellulose and Paper Department of the University of Guadalajara, Mexico for his support with the physical and physicochemical analysis.

\section{References}

Abad, M., Martínez, P. F., Martínez, M. D., Martínez, J. 1993. Evaluación agronómica de los sustratos de cultivo. Acta horticulturae 32: 361-377.

Abad, M., Noguera, P., Burés, S. 2000. Inventario de sustratos y materiales para ser utilizados como sustratos o componentes de sustratos en España. Acta horticulturae 32: 361-377.

Abad, M., Noguera, P., Puchades, R., Maquieira, A., Noguera, V. 2002. Physical-chemical and chemical properties of some coconut coir dusts for use as a peat substitute for containerized ornamental plants. Bioresource technology 82: 241-245.

Abad, M., Noguera, P., Carrión, C. 2004. Los sustratos en los cultivos sin suelo. In: M. Urrestarazu. Tratado del cultivo sin suelo, Mundi-prensa. Madrid, España p. 113-158.

Ansorena, M. J. 1994. Sustratos. Propiedades y caracterización. Mundi-prensa, Madrid, España.172 p.

AOAC, 1984. Official methods of analysis. 14th Ed. Association of official analytical chemist, Washington, DC. USA. $952 \mathrm{p}$.

Bautista, C. A., De León-González, F., Carrillo, G. R., Robles C. 2011. Identification of soil quality indicators for maguey mezcalero (Agave angustifolia Haw.) plantations in southern Mexico. African journal of agricultural research 6: 47954799.
Bernal, M. P., Paredes, C., Sánchez-Monedero, A., Cegarra, J. 1998. Maturity and stability parameter of compost prepared with a wide range of organic wastes. Bioresource technology 63: 91-93.

Bertran, E., Sort, X., Soliva, M., Trillas, I. 2004. Composting winery waste: Sludges and grape stalks. Bioresource technology 95: 203-208.

Bunt, A. C. 1988. Media and mixes for containergrown plants. 2nd Ed. Unwin hyman Ltd, London. UK. 350 p.

Burés, P. S. 1997. Sustratos. Ediciones Agrotécnicas S. L. Madrid, España. 342 p.

Cabañas-Vargas, D. D., Sánchez, M. A., Urpilainen, S. T., Kamilaki, A., Stentiford, E. I. 2005. Assessing the stability and maturity of compost at large-scale plants. Ingeniería Revista Académica 9(2): 25-30.

COMERCAM. 2013. Informe 2009-2012 del consejo mexicano regulador de la calidad de mezcal (COMERCAM) 2009-2012 http://www. comercam.org/?mod=boletin <Access on 24 January $2013>$.

De Boodt, M., Verdonck, O. 1972. The physical properties of the substrates in horticulture. Acta Horticulturae 26: 37-44.

De Boodt, M., Verdonck, O., Cappaert, I. 1974. Method for measuring the waterrelease curve of organic substrates. Acta Horticulturae 37: 20542062.

EFSA, 2007. Opinion of the scientific panel on biological hazards on a request from the european commission on the safety vis-a-a vis biological risk of the mesophilic process of biogas and compost treatment of animal by-products (ABPs). European food safety authority. EFSA Journal 465: 1-16.

Genevini, P., Adani, A., Yeeken, Scaglia, B. 2002. Evolution of humic acid-like and core-humic acid-like during high-rate composting of pig faeces amended with wheat straw. Soil Science and Plant Nutrition 48: 135-141.

Gil de Carrasco, C., Guzman, M., Lorente, F. A., Urrestarazu, M. 1994. Xilem sap extraction: a method. Communications in soil science and plant analysis 27: 1859-1874.

Golveke, C. G. 1977. Biological processing: composting and hydrolysis. En: D.G. Wilson. Handbook of solid waste management. Ed. Van Norstrand Reinhold, New York, USA. p. 197-225.

Herrera, F., Castillo, J. F., Chica, A. F., BellidoLópez, L. 2008. Use of municipal solid waste compost (MSWC) as a growing medium in the 
nursery production of tomato plants. Bioresource Technology 9: 287-296.

Iglesias, J., Perez, G. 1992. Determination of maturity indices for city refuse compost. Agriculture, Ecosystems and Environment 38: 331343.

Íñiguez, G., Lange, S. E., Rowell, R. M. 2001. Utilization of by-products from the tequila industry: Part 1: agave bagasse as a raw material for animal feeding and fibreboard production. Bioresource Technology 77: 25-32.

Iñiguez, G., Flores, S., Martínez, L. 2003. Utilización de subproductos de la industria tequilera. Parte 5. Biodegradación del material de descarne de la industria de curtiduría. Revista Internacional de Contaminación Ambiental 17(2): 83-91.

Íñiguez, G., Parra, J., Velasco, P. A. 2006. Utilización de subproductos de la industria tequilera. Parte 8. Evolución de algunos constituyentes de la mezcla de biosólidos-bagazo de agave durante el compostaje. Revista Internacional de Contaminación Ambiental 22(2): 83-93.

Íñiguez, G., Martínez, G. A., Flores, R. P., Virgen, G. 2011. Utilización de subproductos de la industria tequilera parte 9. Monitoreo de la evolución del compostaje de dos fuentes distinta de bagazo de agave para la obtención de un substrato para jitomate. Revista Internacional de Contaminación Ambiental 27 (1): 47-59.

Klamer, M., Lind, A., Gams, W. 2001. Fungal succession during composting of Miscanthus straw and pig slurry. Acta Horticulturae 549: 37-45.

Lee, B., Kim, J., Chang, W. 2002. Evaluation of stability of compost prepared with korean food wastes. Soil Science and Plant Nutrition 48: 1-8.

Martínez, F. X. 1992. Propuesta de la metodología para la determinación de las propiedades físicas de los sustratos. Acta Horticulturae 11: 55-66.

Martínez-Gutiérrez, G. A., Ortiz-Hernandez, Y. D., Urrestarazu, M., Salas, S. J., Escamirosa-Tinoco, C. 2009. La rotación de cultivos y las propiedades de la cáscara de almendra como sustrato. Revista Fitotecnia Mexicana 32(2): 135-142.

Martínez-Gutiérrez, G. A., Urrestarazu, M. 2012. Cultivo sin suelo en cáscara de almendra, un sustrato sostenible alternativo. Editorial Académica Española. Madrid, España. 152 p.

Marfá, O., Martínez, A., Orozco, R., Serrano, L., Martinez, F. X. 1993. The use of fine grade perlites in lettuce bag cultures. II. physical properties, rheologic effects and productivity. Acta Horticulturae 342: 339-347.

Nakasaki, K., Hideky, Y., Yasushi, S., Hiroshi, K. 1993.
Effects of $\mathrm{pH}$ control on composting of garbage. Waste Management and Research 11(2): 117125.

Noguera, P., Abad, M., Puchades, R., Noguera, V., Maquieira, A., Martinez, J. 1997. Physical and chemical properties of coir waste and their relation to plant growth. Acta Horticulturae 450: 365-373.

Noguera, P., Abad, M., Noguera, V., Puchades. R., Maquiera, A. 2000. Coconut coir waste, a new and viable ecologically-friendly peat substitute. Acta Horticulturae 517: 274-288.

Puustjärvi, V. 1994. La turba y su manejo en la horticultura. Ediciones de horticultura. S. L. Reus. Madrid, España. 123 p.

Richards, D., Lane, M., Beardsell, D. V. 1986. The influence of particle size distribution in pinebark:sand:brown coal potting mixes on water supply, aeration and plant growth. Scientia Horticulturae 29: 1-14.

Ross, M., García, C., Hernández, T. 2006. A full-scale study of treatment of pig slurry by composting: kinetic changes in chemical and microbial properties. Waste Management 26: 1108-1118.

Rynk, R. 1992. On farm composting handbook. Northeast regional agricultural engineering service. http://watershedbmps.com/wpcontent/uploads/2012/03 /01744_FarmCompost. pdf <Access on 15 January 2014>.

SAS Institute. 2002. SAS/STAT User's guide, Software version 9.0. Cary, N.C. USA. 4424 p.

Sundberg, C., Smars, S., Jonsson, H. 2004. Low pH as an inhibiting factor in the transition from the mesophilic to thermophilic phase in composting. Bioresource Technology 95:145-150.

TMECC, 2001. Test methods for the examination of composting and compost. Http:// composting council.org/admin/wp-content/ plugins/wp-pdfupload/pdf/34/tmecc\%20 purpose, $\% 20$ composting $\% 20$ process.pdf $<$ Access on 15 January 2014>.

Urrestarazu, M., Mazuela, P. C., Martínez-Gutiérrez, G. A. 2008. Effect of substrate reutilization on yield and properties of melon and tomato crops. Journal of Plant Nutrition 31: 2031-2043.

Vargas, T. P., Castellanos, R. J., Sánchez, G. P., Tijerina, L. Ch., López, R. R., Ojo de agua, A. J. 2008. Caracterización física, química y biológica de sustratos de polvo de coco. Revista Fitotecnia Mexicana 31 (4): 375-381.

Venegas, G., Lenon, C., Trinidad, S., Gavi, R., Sánchez, G. 2005. Análisis químico de compost 
y efecto de su adición sobre la producción de biomasa en zarzamora. Terra Latinoamericana 23 (3): 285-292.

Warncke, D. D. 1986. Analyzing greenhouse growth media by the saturation extraction method. Hortscience 21: 223-225.

WHO. 2006. WHO guidelines for the Safe Use of Wastewater, Excreta and Greywater. Volume IV. Excreta and greywater use in agriculture. World Health Organization (WHO) press, Geneva, Switzerland. 204 p. http://www.pseau.org/outils/ ouvrages/who safe use wastewater_excreta greywater_v4_en.pdf <Access on 17 January 2014> 